\title{
MEMAKNAI SARASWATI SEBAGAI UPAYA PENCERAHAN DIRI (Kajian Pasal 41 Panaturan)
}

\author{
Komang Suarta \\ Institut Agama Hindu Negeri Tampung Penyang Palangkaraya \\ bawiayahfda@gmail.com
}

$\begin{array}{ll}\text { Riwayat Jurnal - } & \\ \text { Artikel diterima } & :- \\ \text { Artikel direvisi } & :- \\ \text { Artikel disetujui } & :-\end{array}$

\begin{abstract}
Abstrak
Seseorang yang dihadapkan dengan kegelapan, tentu ia akan membutuhkan cahaya agar mampu melangkah dengan benar. Begitu pula halnya dalam hal ini, agama dipegang bagaikan sebuah obor untuk menerangi jalan di dalam kegelapan, agar kita mengetahui mana jalan yang patut dan mana pula jalan yang tidak patut untuk dipijak. Dewasa ini, banyak kita saksikan fenomena-fenomena yang menunjukan perilaku manusia yang dikuasai oleh kegelapan pikiran dengan cenderung melakukan perbuatan-perbuatan asubha karma yang dilarang dalam ajaran Hindu. Hal tersebut bukan saja dilakukan oleh mereka yang memiliki pendidikan rendah, namun juga oleh mereka yang memiliki tingkat pendidikan yang tinggi. Selain dari fenomena yang kita saksikan tersebut, hal serupa juga dikisahkan dalam sejarah kehidupan leluhur Hindu Kaharingan yang melupakan segala bentuk ajaran yang disampaikan oleh Ranying Hatalla (Tuhan) pada keturunan Raja Bunu (manusia) sebelum diturunkan untuk mengisi kehidupan di dunia ini. Hal tersebut diceritakan dalam Pasal 41 Panaturan. Panaturan merupakan kitab suci umat Hindu Kaharingan yang dijadikan pedoman dalam menjalankan kehidupan sehari-hari. Berdasarkan uraian latar belakang di atas, maka adapun rumusan masalah dalam tulisan ini adalah (1) Siapakah Saraswati dalam theologi Hindu?. (2) Bagaimanakah memaknai Saraswati sebagai upaya pencerahan diri (kajian Pasal 41 Panaturan)?. Adapun yang menjadi tujuan dalam tulisan ini adalah (1) Untuk mengetahui Saraswati dalam theologi Hindu, (2) Untuk mengetahui makna Saraswati sebagai upaya pencerahan diri (kajian Pasal 41 Panaturan).

Dalam ajaran Hindu Tuhan adalah sumber dari segala pengetahuan yang ada dan diberi gelar Saraswati.Dengan senantiasa mempelajari, mengingat dan mengimplementasikan pengetahuan yang telah diperoleh, maka sesungguhnya telah memuja Saraswati yakni perwujudan Tuhan sebagai penguasa pengetahuan yang dalam ajaran leluhur Hindu Kaharingan dikenal dengan sebutan Bawi Ayah. Dengan demikian, maka hidup akan senantiasa terarah karena melangkah dengan tuntunan pikiran yang tercerahkan.
\end{abstract}

Kata kunci : Saraswati, Upaya Pencerahan Diri, Panaturan 


\section{Pendahuluan}

Ketika seseorang dihadapkan dengan kegelapan, tentu ia akan membutuhkan cahaya agar mampu melangkah dengan benar. Tanpa cahaya, ia bisa saja tersandung atau masuk dalam lobang yang akan menggagalkan langkahnya untuk mencapai tujuan yang diharapkan. Demikian pula agama dalam kehidupan manusia. Agama berfungsi untuk memberi pengetahuan tentang tujuan dan bagaimana caranya hidup". Dalam hal ini, agama dipegang bagaikan sebuah obor untuk menerangi jalan di dalam kegelapan, agar kita mengetahui mana jalan yang patut dan mana pula jalan yang tidak patut untuk dipijak. Dari hal itulah, maka agama dapat berfungsi sebagai daya dorong untuk berbuat baik atau mempunyai "Motive Power of doing Good”. Untuk mencapai tujuan agama, maka manusia harus mampu menjalankan fungsi yang dimiliki oleh agama tersebut.

Ajaran kesusilaan Hindu menyebutkan begitu banyak hal yang dapat membuat manusia dikuasai oleh kegelapan pikiran, antara lain kama (hawa nafsu), lobha (keserakahan), kroda (kemarahan), moha (kebingungan), mada (kemabukan/minuman keras), matsarya (iri hati), mala (tingkah laku yang kotor), dikuasai dan mabuk oleh sapta timira (7 macam yang membuat mabuk), yakni; Surupa (wajah yang rupawan), Dana (kekayaan), Guna (kepandaian), Kulina (keturunan ningrat), yowana (masa muda), sura (minuman keras), kasuran dan ajaran asubha karma lainnya. Hal-hal tersebutlah yang membuat manusia menjadi tidak mengetahui siapa dirinya atau disebut awidya. Awidya memiliki arti tidak memiliki/tanpa pengetahuan. Dengan demikian, maka hanya dengan memiliki pengetahuanlah manusia akan mendapatkan cahaya yang memberikan pencerahan dalam kegelapan pikirannya.Pemujaan terhadap Saraswati dalam Hindu membuktikan bahwa Hindu memandang pentingnya peguasaan pengetahuan dalam kehidupan manusia.

Dewasa ini, banyak kita saksikan fenomena-fenomena yang menunjukan perilaku manusia yang dikuasai oleh kegelapan pikiran dengan cenderung melakukan perbuatan-perbuatan asubha karma yang dilarang dalam ajaran Hindu. Hal tersebut bukan saja dilakukan oleh mereka yang memiliki pendidikan rendah, 
namun juga oleh mereka yang memiliki tingkat pendidikan yang tinggi. Selain dari fenomena yang kita saksikan tersebut, hal serupa juga dikisahkan dalam sejarah kehidupan leluhur Hindu Kaharingan yang melupakan segala bentuk ajaran yang disampaikan oleh Ranying Hatalla (Tuhan) pada keturunan Raja Bипи (manusia) sebelum diturunkan untuk mengisi kehidupan di dunia ini. Hal tersebut diceritakan dalam Pasal 41 Panaturan. Panaturan merupakan kitab suci umat Hindu Kaharingan yang dijadikan pedoman dalam menjalankan kehidupan sehari-hari. Berdasarkan hal itulah, maka penulis sangat tertarik untuk mengkaji fenomena dengan permasalahan tersebut di atas melalui sebuah judul "Memaknai Saraswati Sebagai Upaya Pencerahan Diri (Kajian Pasal 41 Panaturan).

\section{Pembahasan}

\subsection{Saraswati dan Ilmu Pengetahuan dalam Agama Hindu}

Umat Hindu senantiasa menjadikan susastra-susastra Hindu yang bersumber dari kitab sucinya sebagai pedoman dalam menjalani kehidupannya sehari-hari. Kitab suci agama Hindu disebut Weda. Weda berasal dari kata
"Vid" yang berarti pengetahuan suci. Kitab suci Weda merupakan sumber dari segala ilmu. Ilmu pada dasarnya adalah pengetahuan tentang sesuatu hal atau fenomena, baik yang menyangkut alam atau sosial (kehidupan masyarakat), yang diperoleh manusia melalui proses berfikir. Itu artinya bahwa setiap ilmu merupakan pengetahun tentang sesuatu yang menjadi objek kajian dari ilmu terkait.

Dalam ajaran Hindu, menguasai ilmu pengetahuan adalah salah satu yang akan membuat seseorang memiliki sifatsifat kedewataan sebagaimana yang disampaikan dalam Bhagavadgita XVI.1

Damas ca yajnas ca

Abhayam sattwasamsuddhir

Jnanayoga wyawasthitih

Danam Swadhyayas tapa arjawam

Artinya:

Tak gentar, suci hati, bijaksana, berketetapan, mengabdi, menguasai ilmu pengetahuan, menguasai indria, beryajna dan mempelajari kitab-kitab Weda, meditasi dan kejujuran (Pudja, 2003:345).

Dalam agama Hindu, Tuhan merupakan sumber dari segala Pengetahuan. Sebagai Sumber Pengetahuan, Tuhan diberi gelar dengan sebutan Saraswati. Ada beberapa hal yang dapat menjadi gambaran tentang Saraswati. 
a. Dewi Saraswati digambarkan sebagai sosok wanita cantik, dengan kulit halus dan bersih, merupakan perlambang bahwa ilmu pengetahuan suci akan memberikan keindahan dan kelembutan hati dalam diri.

b. Dewi Saraswati tampak berpakaian dengan dominasi warna putih, terkesan sopan, menunjukan bahwa pengetahuan suci akan membawa para pelajar pada kesahajaan.

c. Dewi Saraswatidigambarkan duduk atau berdiri diatas bunga teratai yang mana semua itu merupakan simbol dari kebijaksanaan dengan kemampuan penyesuaian diri dalam berbagai kondisi lingkungan.

d. Burung Merak; simbol kewibawaan pada orang yang menguasai ilmu pengetahuan.

e. Dewi Saraswati digambarkan memiliki empat lengan yang melambangkan empat aspek kepribadian manusia dalam mempelajari ilmu pengetahuan. Di masing-masing lengan tergenggam empat benda yang berbeda, yaitu:

1) Lontar (buku), adalah kitab suci Weda, yang melambangkan sumber pengetahuan universal, abadi, dan ilmu sejati.
2) Genitri ; melambangkan kekuatan meditasi dan pengetahuan spiritual/kekekalan ilmu pengetahuan.

3) Wina (kecapi), alat musik yang melambangkan kesempurnaan seni dalam ilmu pengetahuan.

4) Damaru (kendang kecil). Damaru menghasilkan suara yang bergetar. Dalam kitab Hindu suara yang bergetar dari suku kata Omyang suci dipercaya sebagai sumber dari penciptaan. Sebuah Damaru pada salah satu tangan mengandung makna bahwa ia menyangga seluruh ciptaan di tangannya, mengatur sesuai dengan keinginannya.

f. Angsa merupakan simbol yang berkaitan erat dengan Saraswati sebagai wahana (kendaraan suci). Angsa juga melambangkan penguasaan atas Wiweka (daya nalar) yakni memiliki kemampuan memilahmilah antara yang baik dan yang buruk. Angsa berenang di air tanpa membasahi bulu-bulunya, yang memiliki makna filosofi, bahwa seseorang yang bijaksana dalam 
menjalani kehidupan layaknya orang biasa tanpa terbawa arus keduniawian.

Berdasarkan penjabaran tentang simbol-simbol Saraswati di atas, maka sangat jelas bahwa Hindu mengajarkan bahwa dengan mempelajari ilmu pengetahuan dan mengamalkannya dalam kehidupan sehari-hari, maka sesungguhnya kita telah melakukan persembahan suci yang menghantarkan pada Tuhan sebagai sumber ilmu pengetahuan itu sendiri. Hindu juga memberikan penjelasan tentang keutamaan bagi mereka yang memiliki pengetahuan, karena persembahan berupa pengetahuan dikatakan sebagai persembahan yang paling utama dari persembahan lainnya sebagaimana yang diajarkan dalam Bhagavadgita IV.33.

Sreyan drawyamayad yajnaj

Jnanayajnah parantapa

Sarwam karma'khilam Partha

Jnane parisamapyate (Pudja, 2003: 116)

Artinya:

Persembahan berupa ilmu pengetahuan, wahai Arjuna lebih mulia dari persembahan materi; dalam keseluruhannya semua kerja ini akan mendapat apa yang diinginkan dalam ilmu pengetahuan, oh Partha.
Demikianlahkeagungan yang akan dimiliki oleh orang-orang yang senantiasa memuja Saraswati sebagai sumber dari ilmu pengetahuan dan mengamalkannya dalam kehidupan sehari-hari.

\subsection{Memaknai Saraswati sebagai Upaya Pencerahan Diri (Kajian Pasal 41 Panaturan)}

Umat Hindu Kaharingan adalah umat Hindu yang berasal dari keturunan Suku Dayak yang mendiami Pulau Kalimantan. Mereka berasal dari keturunan Manyamei Tunggul Garing dan Kameluh Putak Bulau Janjulen Karangan Limut Batu Kamasan Tambun, yakni sepasang manusia pertama yang diciptakan oleh Ranying Hatalla/ Tuhan. Dari sepasang manusia pertama tersebut, terlahirlah anak laki-laki kembar tiga yang diberi nama Raja Sangen, Raja Sangiang dan Raja Bunu. Raja Sangen dan Raja Sangiang telah ditakdirkan untuk tinggal di kahyangan/alam atas, sementara itu keturunan Raja Bunu ditakdirkan diturunkan ke Pantai Danum Kalunen/bumi ini. Sebelum diturunkan untuk mengisi permukaan bumi, mereka telah diajarkan tentang tata cara menjalani kehidupan di dunia ini serta cara mereka kelak kembali ke Pantai Danum 
Sangiang/Salam atas ketika mengalami kematian. Ajaran itu dituturkan secara turun temurun secara lisan untuk diingat dan dilaksanakan dalam kehidupan sehari-hari.

Pasal 41 Panaturan pada intinya adalah menceritakan tentang "Bawi Ayah Hadurut Bara Lewu Telu Nanturung Pantai Danum Kalunen" yaitu turunnya Bawi Ayah dari Alam Atas menuju tempat kehidupan manusia, yaitu di dunia ini.

Amun kalute ampin kakare taluh handiai, huang pambelum anak esun Raja Bunu mijen Pantai Danum Kalunen, ije jadi uras nalingau kakare ajar Ranying Hatalla, te ranying Hatalla hamauh hayak nyahuan raja Uju Hakanduang Kanaruhan Hanya Basakati uka hadurut nanturung Lewu Telu Kalabuan Tingang Rundung Epat Kalihulun Talawang (Panaturan, Pasal 41.2)

Artinya:

Memperhatikan keadaan kehidupan anak-cucu Raja Bunu yang hidup di Pantai Danum Kalunen yang sudah banyak melupakan ajaran Ranying Hatalla, maka oleh sebab itu Ranying Hatalla berfirman dan memerintahkan Raja Uju Hakanduang Kanaruhan Hanya Basakati agar supaya segera turun ke Lewu Telu Kalabuan Tingang Rundung Epat Kalihulun Talawang.
Bunyi ayat tersebut menggambarkan bahwa setelah beberapa lapis keturunan, apa yang telah diajarkan oleh Ranying Hatalla dilupakan oleh mereka di dunia ini, sehingga kegelapan pikiran menyelimuti manusia. Pali-pali/ pantangan/larangan kehidupan dilanggar, sehingga terjadi kekacauan dalam kehidupan manusia. Penyakit dan sebagainya mengganggu, sehingga mereka mengalami penderitaan. Menyaksikan fenomena tersebut, maka Ranying Hatalla dengan sifat maha kasihNya kemudian memerintahkan Raja Uju Hakanduang agar segera mengutus Bawi Ayah ke dunia ini untuk mengingatkan kembali ajaran yang pernah disampaikan sebelumnya. Untuk mengingat cerita Bawi Ayah tersebut, maka Tatu Hiang/ leluhur Dayak secara turun-temurun meriwayatkannya dari sebuah generasi kegenari berikutnya dalam cerita Tetek Tatum.

Diceritakan pada masa yang lalu, dari Pengarang Jaman Tetek Tatum, di pertengahan Sungai Kahayan ada beberapa kampung yang bernama Tangkahen Tutuk Rantau, Tangkahen Tutuk Busung dan Tangkahen. Tiga Kampung ini tidak berjauhan, hanya 
Tangkahen Tutuk Rantau dan Tangkahen yang memiliki Tarusan Halange (sungai kecil yang menghubungkan"Halange").

Tetua kampung tersebut yakni :

1. Tangkahen Tutuk Rantau bernama Tingang

2. Tangkahen Tutuk Busung bernama Ringkai dan Tumbung

3. Tangkahen bernama Hanggarung

Mereka berempat ini semuanya laki-laki dan semuanya bisa bersatu/bekerjasama merangkul masyarakat kampung hidup bertani, berusaha dengan semangat, berkebun. Karena pekerjaan mereka berempat ini, maka masyarakat kampung tersebut tidak pernah mengalami kekurangan. Demikanlah sedikit cerita yang menceritakan Tangkahen "Kampung Tiga" tersebut. Demikianlah Ayah serta orang kampung menerima dan menghargai mereka berempat menjadi Tetua mereka.

Suatu hari ketika menjelang fajar, yakni purnama pada bulan ketiga, mereka berempat kumpul di rumah Hanggarung, di Kampung Tangkahen. Saat pertengahan pagi menjelang siang, mereka berempat membicarakan perencanaan masyarakat untuk tahun depan. Tiba-tiba mereka berempat mendengar suara Sangahem dan suara itu berkata; "Bolehkan masuk pamanbapak"? Mendengar suara tersebut, Hanggarung berdiri dan langsung melihat dasar tangga. Terlihat ada seorang lakilaki mendatangi tangga serta kelihatannya gagah perkasa. Hanggarung berkata : "Silahkan masuk nak, kami ada di dalam!". Mendengar suara tersebut, lakilaki itu langsung menaiki anak tangga dan lagsung masuk ke dalam rumah diiringi oleh Haggarung menuju tempat mereka berempat tadi duduk, langsung saja mereka duduk bersama dan menyediakan tempat Penginangan serta mempersilahkannya menginang dan merokok. Mereka bersama-sama menginang, dan saat itulah Ringkai bertanya :

"Bagaikan bertanya melanjutkan
pembicaraan Tingang Aken
(sebutan anak-keponakan yang
memiliki pasangan kata dengan
Burung Anak); berapa orang
kedatangan Tingang Aken serta
mau kemana sehingga sampai pada
rumah Tingang Mamam
(pamanmu) Hanggarung saat ini".

Mendengar perkataan itu, maka berkatalah ia menjawabnya :

Tidak ada salahnya Paman menanyakan perjalanan Tingang 
Akem, bahwa perjalanan saya hanyalah sendiri, tidak berdua ataupun bertiga. Datang dari Batang Danum Jalayan dan ini sudah 7 tahun lamanya perjalanan saya mengelilingi dunia ini (Bumi), melihat dan mencari sebuah kampung yang cocok bagi tempat kami dari Lewu Telu Kalabuan Tingang (alam atas), kami akan turun ikut dengan kalian di alam manusia (Bumi) selama 7 tahun sesuai perintah Ranying Hatalla Langit. Perjalananku untuk manusia ini mencari Sungai, Kampung yang tanahnya bisa menjadi tempat kami tinggal selama 7 tahun.Selama perjalanan 7 tahun $k u$ ini, barulah sekarang menjumpai kampung yang diharapkan yang sesuai dengan kehendak kami Lewu Telu, yakni kampung Tangkahen tuh.Bersama ini aku menemui kalian berempat dari 3 kampung ini. Apakah kalian berkenan 3 kampung ini menjadi tempat bagi kami selama 7 tahun, banyaknya kami yang akan ikut turun nanti dari Lewu Telu 160 orang perempuan dan 160 orang laki-laki. Masuk dari Sungai Sangkalila, masuk dari Sungai Letai Runjan. Yang perempuan akan tinggal di kampung Tangkahen ini, sementara yang laki-laki akan tinggal di Tangkahen Tutuk Rantau.

Mereka berempat menjawab, katanya :

Permohonan kalian dari Lewu Telu itu tidak ada salahnya. Hanya satu Tingang Aken, kami ketahui bahwa kalian penghuni Lewu Telu semuanya mempunyai dan memelihara berbagai kesaktian (jimat dan lain sebagainya) yang tiada bandingnya, begitu pulanya para wanitanya, takut rasanya jika kami tidak mampu memeliharal menjaga pantangan dari kesaktian kalian tersebut, pantangan garu jaman dahulu tersebut.

Mendengarkan hal itu, lalu orang tersebut kembali menjawab :

Tidak apa-apa Paman semuanya, kami sudah mengetahui bagaimana kalian manusia.Oleh karena itu, aku disuruh oleh mereka dari Lewu Telu agar memilih kampung di Bumi ini.Tidak apa-apa saja jika demikian halnya wahai Tingang Aken.

Kami ini bertanya : siapa nama

Tingang Aken? Bersama itu pula ia menjawab pertanyaan pamannya :

Aku ini datang dari Batang Danum Jalayan, jadi sebut saja namaku Ungku Jalayan; dan juga memang itu namaku serta memudahkan paman mengetahuinya. Tidak apaapa Paman, karena memang aku yang menyebut namaku demikian, jangan kalian Pantai Danum Kalunen (Manusia) sungkan menyebut namaku demikian.Kalau ada kalian manusia atau orang dari alam Sangiang mencari Aku, sebut saja namaku "Ungku Jalayan". Aku ini 7 hari ikut kalian di kampung ini. Aku mau melihat-lihat kampung ini, kalau saja ada pantangan dari kesaktian/garu kami Lewu Telu yang salah biar 
aku lihat dulu.Setelah ketujuh harinya, kalau tidak ada kalian yang melihat aku, jangan kalian repot dan bingung mencari aku. Selama 7 hari ini kalian jangan repot-repot menyediakan makanan untukku, karena sudah cukup Pinang bekalku.

Setelah percakapan mereka berlima selesai, dia (Ungku Jalayan) turun dan langsung berjalan. Mereka berempat sama-sama diam, setelah itu selama tenggang waktu menginang mereka tidak ada yang berbicara, barulah Ringkai akhirnya berkata :

Apakah orang tersebut orang baik-baik atau orang/ sesuatu yang tidak baik.

Para wanita yang ada di dalam rumah semuanya keluar menuju tengah ruangan rumah. Tumbung berkata :

Kita semua harus tetap waspada, malam nanti kita memberitahukan Antang Patahu agar mereka menceritakan kepada kita semua siapa orang tersebut, agar mereka tetap memelihara kampung kita ini. Keinginanmu benar sekali, kata Hanggarung; Rumah siapa kita jadikan tempat manawurnya? Sahut isterinya Hanggarung! Sebaiknya dirumah ini saja, karena merupakan tempatnya bertamu. Sepakat semua kehendak mereka di rumah Hanggarung.

Malam harinya kemudian mereka berkumpul kembali di Rumah
Hanggarung. Pada saat Tumbung Manawur, Ungku Jalayan datang serta bertanya bagaikan adat orang yang bertamu. Silahkan masuk Tingang Aken, kata Hanggarung. Ia langsung masuk rumah, dan duduk di dekat Tumbung yang sedang Manawur. Tumbung berhenti sebentar Manawur, dan serta merta berkata :

Kami ini kalau saatnya bulan purnama tiba, maka kami mengundang Antang Patahu agar tetap memelihara kami di kampung ini dari beratus penyakit dan sebagainya. Baik sekali Paman, sekalian agar membersihkan Tanah dari kampung ini pada bagian hilir tempat Bawi Ayah (160) orang yang akan turun bersama kalian Manusia. Begitu pula bagian Kampung Tangkahen Tutuk Rantau di sebelah hilirnya untuk Pambujang Linga Danum Jalayan (laki-lakinya) (160) orang yang juga ikut turun, agar melenyapkan Panas/ sial tanah-air, seandainya ada yang penghuni gaib yang tinggal disana agar kiranya mereka pindah dari tempat tersebut. Bisa saja Aken! Tumbung melanjutkan Tawurnya sampai selesai.

Ungku Jalayan mendengarkan dengan seksama suara tawur tersebut sampai selesai. Selesai melaksanakan hal tersebut, warga masyarakat pulang ke rumahnya masing-masing, sementara 
Ungku Jalayan tidur di rumahnya Hanggarung.

Setiap malam warga kampung kumpul di rumah Hanggarung, mereka semua ingin mendengar cerita Ungku Jalayan membicarakan mahluk di atas langit, serta ada pula yang bertanya pada Ungku Jalayan kemana arah/tujuan perjalanan Bawi Ayah serta Pambujang Linga Danum Jalayan turun mendatangi alam manusia dan langsung tinggal di Kampung Tangkahen tersebut. Karena itulah, Ungku Jalayan segera menjawabnya dengan bercerita panjang untuk warga kampung, katanya :

Pada saat dulu kala, di Lewu Batu Nindan Tarung Rundung Liang Angkar Bantilung Nyaring, Tunggul Garing Janjahunan Laut mereka berdua Putak Bulau Janjulen Karangan Limut Batu Kamasan Tambun memiliki 3 anak, yakni; Maharaja Sangen, Maharaja Sangiang dan Maharaja Bunu. Maharaja Sangen dan Maharaja Sangiang melahirkan orang di alam Sangiang dari Tasik Ambun sampai Tasik Rumpang Matan Andau. Maharaja Bunu diturunkan oleh Ranying Hatalla dan Raja Uju Hakanduang dahulu kala ke alam Manusia (Bumi), kampung tempat yang bisa mengalami Kematian, Kampung Pinjaman. Dan mereka melahirkan kalian manusia, kalian semuanya, paman!
Sebelum ia diturunkan, 3 tahun Ranying Hatalla dan Raja Uju Hakanduang telah menceritakan untuknya berbagai cara kehidupan yang baik di Pantai Danum Kalunen agar anak cucunya berlapis tetap mengingat dan menggunakan janji Ranying Hatalla, Raja Uju agar mereka Manusia tetap mengetahui Ranying Hatalla Langit dan Raja Uju Hakanduang yang menguasai segala yang ada ini. Ia telah membuat dan menjadikannya. Bersama itu agar mengetahui ada dua tempat yakni Pantai Danum Kalunen Luwuk Kampungan Bunu/ Lewu Injam Tingang Rundung Nasik Nampui Burung dan Pantai Danum Sangiang Luwuk Guhung Jalayan, inilah tempat kami, tempat Raja Uju, tempat Ranying Hatalla Langit. Pada saat Maharaja Bunu sampai 14 lapis setelah ia, keturunannya di Pantai Danum Kalunen belum ada yang berubah sebagaimana mereka melaksanakan berbagai pekerjaan yang diharapkan mengikuti petunjuk/ pesan dari Maharaja Bunu. Dalam 14 lapis lagi, banyak yang sudah tertukar susunan pekerjaan itu.Bersamaan dengan semakin banyaknya jumlah kalian manusia, dalam 14 lapisan lagi banyak hal yang telah dilupakan susunan pekerjaan tersebut. Dalam 14 lapis sampai saat ini, kalian banyak kekurangannya dari apa yang telah disampaikan. Kalian manusia jumlahnya telah banyak, berbagai pantangan hidup-mati sudah tidak ditaati lagi atau mengikuti Pantai Danum Sangiang Luwuk Guhung Jalayan, berlapis sampai pada 
Ranying Hatalla Langit, banyak manusia yang tidak mengetahuinya. Pantangan dan Sial Angui Bungai Mama Lengai Bungai sudah banyak yang mengikuti kehidupan manusia.Gigi merasuk/ berubah menjadi Hambaruan orang yang tidak mengingat janji Ranying Hatalla Langit yang telah diceritakan oleh Maharaja Bunu untuk manusia dahulu kala. Karena aku telah mengelilingi Alam manusia ini (Pantai Danum Kalunen) melihat Sungai, kampung, hanya menjumpai hanya kampung ini saja yang tidak disinggahi oleh Pantangan dan Sial Angui Bungai Mama Lengai Tingang, serta mampu untuk orang atas tinggal, tidak akan merubah/ melenyapkan/ merusak kesaktian serta Garu Kuno. Yang akan turun nanti adalah 160 perempuan dan 160 laki-laki dari Lewu Telu. Ada Sangiang Laut Mangantung yakni Raja Cina Bakuncir Panjang, Raja Lenda Bagadung Batu, Raja Siam yang memiliki Tembakau enak, Raja Kaling Babilem Pamungkal Garantung, Raja Garahasik Kintum Kamarewut Badil, mereka inilah yang akan mengelilingi dunia ini, mengajar dan mengingatkan mereka yang berasal dari leluhur yang lainnya.

Karena Ranying Hatalla Langit melihat keturunan anak cucu Pantai Danum Kalunen sudah banyak bagai Burung terbang tak mengenal arah, sebagaimana yang ku katakana tadi maka IA menyuruh keturunan Maharaja Sangen dan Maharaja Sangiang turun ke Pantai Danum Kalunen agar mengajarkan kalian berbagai cara melangsungkan kehendak yang dilakukan secara benar berdasarkan petunjuk-Nya selama 7 tahun, agar kalian manusia tidak tersesat sampai kalian pulang ke Lewu Tatau Dia Rumpang Tulang Rundung Raja Isen Kamalesu Uhat bersatu dengan leluhur Maharaja Bunu di sebuah tempat yang teah diatur oleh Ranying Hatalla dahulu kala. Nanti kalau mereka semuanya telah turun ke Pantai Danum Kalunen ini, maka yang laki-laki akan mengajar laki-laki, bagi yang perempuan akan mengajar para perempuan. Kampung Tangkahen untuk mereka yang perempuan, sementara Tangkahen Tutuk Rantau bagi yang laki-laki.

Setelah Bawi Ayah dan Pambujang Linga Jalayan menyelesaikan tugas untuk mengajarkan pengetahuan yang telah dilupakan tersebut, Semuanya diminta untuk berkumpul, maka Raja Pampulau Hawun berkata :

7 tahun 2 bulan kami dari Lewu Telu Ije Kalabuan Tingang sudah mengembara ke Pantai Danum Kalunen, menyambung pesan yang disampaikan Ranying Hatalla Langit, menyampaikan kepada kalian Pantai Danum Kalunen tentang tata cara kalian hidup di Pantai Danum Kalunen, agar kalian bisa hidup bersatu padu, agar kalian tidak tersesat ketika kembali ke Lewu Tatau. Sudah disediakan oleh Ranying Hatalla Langit semenjak dahulu kala, sudah disiapkan semuanya oleh leluhur kalian Maharaja Bunu. Secara 
lengkap telah kami sampaikan, dari yang terkecil sampai pada yang terbesar selama 7 tahun 2 bulan ini.Satupun tak ada yang tertinggal. Sebaiknya kalian tetap mengingat dan melaksanakannya, sebab diantara kalian manusia ini telah terdapat begitu banyak Manifestasi Kemahakuasaan Ranying Hatala yang lepas dari aturan Ranying Hatalla Langit, seperti Pali, Tulah, Sial kawe Angui Bungai Mamalengai Tingang yang semuanya menginginkan kalian manusia mengikuti mereka. Siapa saja kalian manusia yang ikut mereka, kalau ia mengalami kematian, anak cucunya akan melaksanakan upacaraTiwah untuk mengantarkan Liau Haring Kaharingan menuju Lewu Tatau, raja-raja di semua pintu langit semua berkumpul di Lewu Tatau, pada saat itulah Ranying Hatala memerintahkan Raja Panimbang Darah Kanaruhan Panaraju Isi, menimbang/ mengadili seluruh Liau Haring Kaharingan yang diantar. Liau kepunyaan Tulah Pali itu akan diantar ke tempat Liau Anak Sarau, Liau kepunyaan Sial Liau kepunyaan Angui Bungai Mamalengai Tingang itu akan diantar ke Angui Bungai. Liau milik Ranying Hatalla Langit akan diantar ke tempat-Nya, yakni ke Lewu Tatau bersatu dengan leluhurnya Maharaja Bunu. Ini aku ulang agar kuat ingatan kalian wahai manusia, serta jelas bagi kalian manusia mengetahui kelak jalan kalian kembali ke Lewu Tatau untuk selamanya.Karena kami ini turun dan ikut kalian di Pantai Danum Kalunen adalah untuk mengajarkan serta meriwayatkan kepada kalian kembali Sabda Ranying Hatalla kepada leluhur kalian yakni Maharaja Bunu dahulu kala.Setelah kami ini, tidak ada orang Pantai Sangiang turun mengajar kalian manusia seperti kami ini.

Pesan inti dari hal tersebut adalah bahwa pengetahuan tersebut tidak hanya berhenti untuk dipelajari dan diingat semata, namun hendaknya juga diimplementasikan dalam kehidupan sehari-hari, sehingga akan bermanfaat dalam kehidupan kita. Dengan demikian, maka pikiran kita tidak dikuasai oleh kegelapan dan sebaliknya pikiran akan jernih yang pada akhirnya akan membuat kecerdasan/budhi tercerahkan sebagaimana halnya Sang Budha. Dalam Manawa Dharma Sastra, menyatakan bahwa pengetahuan adalah salah satu sarana untuk pembersihan dan pensucian diri.

Adbhirgatrani cuddhyanti Manah satyena cuddhyanti

Widhya tapobhyam bhutatma Bhuddir Jnanena cuddhyanti (Manawa Dharma Sastra V. 109).

Artinya :

Tubuh disucikan dengan air Manah disucikan dengan kejujuran Atma disucikan dengan tapa brata Budhi disucikan dengan ilmu pengetahuan (Pudja \& Sudhartta, 2002:311). 
Setelah Raja Pampulau Hawun mengakhiri perkataannya, mereka Bawi Ayah dan Pambujang Linga memberi masing-masing 1 buah pinang kepada seluruh yang hadir, Bawi Ayah membagikan pada mereka yang perempuan, sementara itu Pambujang Linga membagikannya untuk yang lakilaki. Kameluh Tempun Taiawun dengan mereka semua, katanya :

Buah pinang ini diberikan kepada kalian semuanya, karena selama 7 tahun ini tidak ada diantara kalian yang memakannya, agar kalian sama merasakannya makanan kami Pantai Sangiang, karena setelah ini roh pinang ini akan kami ambil dan kami bawa pulang kembali kealam atas. Siapa diantara kalian yang ikut perjalanan sangiang kealam atas pada saatnya nanti, barulah ia akan memakan buah pinang ini. Pohon pinang ini tetap ditinggalkan untuk kalian manusia, kalian jaga dengan baik, bisa kalian menanam buahnya, tapi orang yang menanamnya pernah didinginkan dengan mengoleskan darah, agar ia tidak tulah/ sakitsakitan dan sebaginya. Buah pinang ini bisa saja kalian makan, dan merasakan perbedaan rasanya dari memakan buah yang kami berikan saat ini.

\section{Penutup}

\subsection{Kesimpulan}

Dari pembahasan sebelumnya, maka dapatlah disimpulkan bahwa dalam ajaran Hindu Tuhan adalah sumber dari segala pengetahuan yang ada. Dengan senantiasa mempelajari, mengingat dan mengimplementasikan pengetahuan yang telah diperoleh, maka sesungguhnya telah memuja Saraswati yakni perwujudan Tuhan sebagai penguasa pengetahuan. Dengan demikian, maka hidup kita akan senantiasa terarah karena melangkah dengan tuntunan pikiran yang tercerahkan.

\subsection{Saran}

Sebagai umat Hindu kita hendaknya senantiasa selalu mempelajari, mengingat dan mengimplementasikan pengetahuan suci yang telah diturunkan Tuhan melalui manifestasi-Nya sebagaimana Tuhan yang telah menurunkan pengetahuannya kepada manusia di dunia ini melalui Bawi Ayah, sehingga akan bermanfaat untuk mencerahkan diri dari kegelapan dan kelak mengantarkan kita pada Tuhan sebagai sumber dari segala yang ada. 


\section{Daftar Pustaka}

Jalaludin. 2004. PsikologiAgama. Jakarta : Raja Grapindo Persada.

Kajeng, I Nyoman dkk. 1977. Sarasamuccaya. Surabaya : Paramita.

Majelis Besar Agama Hindu Kaharingan. 2005. Panaturan. Palangka Raya : Kanwil Depag Prop. Kalteng.

Oka Netra, Anak Agung Gde. 1994. Tuntunan Dasar Agama Hindu. Surabaya : Paramita.

Pudja, G \& Rai Sudharta, Tjokorda. 2002. Manawa Dharma Sastra. Jakarta : Felita Nursatama Lestari.

Pudja, G. 2003. Bhagawad Gita. Surabaya : Paramita.

Titib, I Made. 2003. Theologi dan Simbol-simbol Dalam Agama Hindu. Surabaya : Paramita. 